\title{
RESPONSE OF SOME SUGAR BEET GENOTYPES TO NITROGEN FERTILIZATION LEVELS UNDER NEWLY RECLAIMED SOIL CONDITIONS
}

\author{
Al-Labbody, A.H.S.A.; Aly, M.S.M. and Abo El-Ghait, R.A. \\ Sugar Crops Research Institute, Agricultural Research Center Giza, Egypt. \\ ABSTRACT \\ Two field experiments were conducted during 2009/2010 and \\ 2010/2011 seasons in Koum Ousheem district, El-Fayoum Governorate. \\ The major goal was to study the response of five multigerm sugar beet \\ varieties namely; Oscar poly, Desprez poly N, Pleno, Nejma and H poly \\ to three nitrogen fertilizer levels, i.e., 100,120 and $140 \mathrm{~kg} \mathrm{~N} / \mathrm{fed}$. \\ The obtained results revealed that Desprez poly $\mathrm{N}$ variety \\ significantly increased in growth traits, i.e., root diameter, root fresh \\ weight and sugar yield/fed, while Nejma variety significantly surpassed \\ in sucrose \% and root yield/fed, and reduction in impurities\% in both \\ seasons. \\ Application of $140 \mathrm{~kg} \mathrm{~N} / \mathrm{fed}$. maximized yield productivity, \\ represanted by improved average root weight, root and sugar yields/fed. \\ However, juice impurities were increased as nitrogen level was \\ increased from 100 to $140 \mathrm{~kg} / \mathrm{fed}$. On the contrary, a gradual reduction \\ in sucrose \% has been detected with the increase in nitrogen level over \\ $120 \mathrm{~kg} / \mathrm{fed}$. \\ The interaction between Desprez poly $\mathrm{N}$ variety and nitrogen \\ fertilization up to $140 \mathrm{~kg} \mathrm{~N} / \mathrm{fed}$. recorded the highest values in root and \\ sugar yields/fed. Under the conditions of this study productivity of sugar \\ beet varieties could be maximize by supply sufficient nitrogen \\ fertilization levels from 120 to $140 \mathrm{~kg} \mathrm{~N} / \mathrm{fed}$.
}

Key words: Sugar beet genotypes, Different nitrogen levels and In newly reclaimed soils

\section{INTRODUCTION}

Sugar beet ranks the second sugar crop after sugar cane crop over all the world where it provides about $40 \%$ of the world sugar production. All sugar beet genotypes cultivated in Egypt are imported from foreign countries, so, it is preferable to evaluate them under Egyptian conditions especially under newly reclaimed soil to select the best suited ones. The varital differences in gen make up expression may be throw some light on their relative importance and behavior through the growing season. Osman et al (2003) showed that sugar beet Kawemira cultivar was superior in sucrose\%, root, top and sugar yields/fed compared to cultivars Top, Lola, and Pleno. Aly (2006), Azzazy et. al. (2007) and El-Sheikh et. al. (2009) found significant differences among sugar beet varieties varied significantly for root fresh weight/plant, root and sugar yields/fed, while root length and diameter as well as sucrose and purity\% did not differ significantly. Sugar beet variety KWS-9422 gave the highest root and sugar yields/fed. Enan $\boldsymbol{e t}$. al. (2009) revealed that sugar beet varieties differed significantly in all studied traits in both seasons. Sugar yield in the $1^{\text {st }}$ season, Farida variety gave a significant increase for sugar yield, juice quality, sucrose and purity\% while it recorded the lowest values of impurities (Na, $\mathrm{K}$ and $\mathrm{N} \%$ ). Abd El-Aal et. al. (2010) detected significant variation in yield productivity and root quality among the varieties. Kawemira and Gloria varieties gave the

Fayoum J. Agric. Res. \& Dev., Vol. 26, No.1, January, 2012 
highest sugar yield followed by Nejma. On the other hand, Lola variety exhibited the lowest sugar yield/fed.

Nitrogen application to sugar beet cultivation has been found essential for yield determination. This is because nitrogen has pronounced effects on growth and physiological processes of sugar beet, even to the extent of causing large changes in the physiological and chemical traits of yield at harvest. Root quality is a combination of all chemical and physical aspects of beet root which influence processing and hence yield of sugar and its product Oldfield $\boldsymbol{e t}$. al. (1979). The optimum dose of nitrogen needed by sugar beet is greatly affected by many factors such as soil type, length of growing period, irrigation system, sugar beet variety ... etc. In general, the literature cleared that sugar beet did not produce profitable crop under shortage of nitrogen. Nevertheless, high $\mathrm{N}$ levels decrease sucrose content and hence increased the content of molasses forming compounds, especially the amount of alpha amino $\mathrm{N}$ Vandergeten and Venstallen (1991). Meantime, additional rates of nitrogen fertilizer were accompanied by gradual and significant increases in yields and quality. El Hinnawy et. al. (2002) and Shafika and El Masry (2006) found that increasing nitrogen rates from 60 up to $100 \mathrm{~kg} /$ fed significantly increased root growth and yield traits, while declined juice quality traits. Neamet Alla (2004) reported that there was a non significant effect on root length by applying 20, 40 and $60 \mathrm{~kg} \mathrm{~N} / \mathrm{fed}$. While, increasing $\mathrm{N}$ level from 90 to $140 \mathrm{~kg} / \mathrm{fed}$ did not affect sucrose. High mineral nitrogen levels are being added to sugar beet in order to maximize its productivity in clay soils (Abou Zeid and Osman 2005). Leilah et. al. (2005) found that adding $250 \mathrm{~kg} \mathrm{~N} / \mathrm{ha}(100 \mathrm{~kg} \mathrm{~N} / \mathrm{fed})$ produced the highest values of length, diameter and fresh weight of roots, foliage fresh weight as well as root, top and sugar yields/ha under the newly reclaimed soil in Egypt. Pytlarzkozicka (2005) showed that increase of nitrogen level from 90 to $180 \mathrm{~kg} / \mathrm{ha}$ caused a significant increase in average root weight, potassium and nitrogen contents in roots, but it lowered sugar content. High nitrogen levels are recommended in sandy soils, but are subjected to leaching losses causing water pollution (Aly et. al. 2009). Abd El-Aal et. al. (2010) revealed that nitrogen level of $120 \mathrm{~kg} / \mathrm{fed}$ maximized yield productivity, root weight, root and sugar yield. However, juice impurities were increased as nitrogen level increased to $140 \mathrm{~kg} \mathrm{~N} / \mathrm{fed}$. A gradual decrease in sucrose \% was observed by the increase nitrogen level over $80 \mathrm{~kg} / \mathrm{fed}$. Osman et. al. (2010) found that nitrogen fertilizer at $100 \mathrm{~kg} / \mathrm{fed}$ recorded the highest root and sugar yields which amounted to $29.5,2513$ and 5.50, $4.65 \mathrm{t} / \mathrm{fed}$, respectively in both seasons. The present study aimed to evaluate five suger beet verieties grown in newly reclaimed soil fertilized by three nitrogen levels.

\section{MATERIALS AND METHODS}

Two field experiments were conducted at Koum Ousheem district, ElGomhoria village, El-Fayoum Governorate during 2009/2010 and 2010/2011 seasons. The soil of experimental site has a sandy loam texture (chemical and mechanical analysis are presented in Table 1). Five multigerm sugar beet varieties were used in this study as shown in Table (2). 
RESPONSE OF SOME SUGAR BEET GENOTYPES TO NITROGEN... 80

Table (1) : Mechanical and chemical analysis of the experimental site in 2009/2010 and 2010/2011 seasons.

\begin{tabular}{ccc|}
\hline Mechanical and chemical analysis & \multicolumn{2}{c|}{ Seasons } \\
\cline { 2 - 3 } & $2009 / 2010$ & $2010 / 2011$ \\
\hline Clay \% & 30.5 & 31.1 \\
Silt \% & 22.8 & 23.4 \\
Sand \% & 46.7 & 46.5 \\
pH & 8.3 & 8.2 \\
Available N (p.p.m) & 8.1 & 8.3 \\
\hline
\end{tabular}

Table (2): Varieties and their origin country

\begin{tabular}{c|c|c|}
\hline No. & Variety & Country of origin \\
\hline 1 & Oscar poly & Denmark \\
2 & Desprez poly N & France \\
3 & Pleno & France \\
4 & Nejma & Sweden \\
5 & H-poly & Sweden \\
\hline
\end{tabular}

In each experiment, a split plot design with three replications was used. Main plots were devoted for nitrogen fertilization levels $(100,120$ and $140 \mathrm{~kg}$ $\mathrm{N} / \mathrm{fed}$ ) and sugar beet varieties were arranged in the sub plots. Plot size was $16.8 \mathrm{~m}^{2}$ consists of 4 rows (60 $\mathrm{cm}$ apart) and $7 \mathrm{~m}$ long (1/250 for fed.). Planting dates were carried out on October $3^{\text {rd }}$ and $5^{\text {th }}$ in the $1^{\text {st }}$ and $2^{\text {nd }}$ seasons, respectively. Nitrogen fertilizer was added in the form of ammonium nitrate $(33.5 \% \mathrm{~N})$ in two equal doses, the first was added after thinning at 4-leaf stage and the other dose was after 3 applied 30 days later. The other recommended agricultural practices for growing sugar beet were followed. At harvest, two guarded rows were taken from each plot to determine root yield/fed. A sample of ten roots was taken randomly from each plot to estimate the following characteristics i.e. root fresh weight/plant, root length $(\mathrm{cm})$ and diameter $(\mathrm{cm})$ thereafter, analyzed for sucrose and impurities $\%(\mathrm{Na}, \mathrm{K}$ and $\alpha$ - amino $\mathrm{N} \%)$. Sugar polarization (Sucrose \%) was polarimetrically determined on a lead acetate extract of fresh macerated root according to Le Docte (1927). Sodium and potassium were determined using Flame Photometer as described by Page (1982). Alpha amino nitrogen was determined according to the method of Carruthers et al. (1962). Sugar yield (ton/fed) = Root yield (ton/fed) x sucrose $\%$. Data were statistically analyzed according to Snedecor and Cochran (1981).

\section{RESULTS AND DISCUSSION}

1. Varietal differences:

The obtained results in Table (1) clear that varieties significantly differed in root growth traits, sucrose $\%$, root and sugar yields and impurities contents in both seasons. Oscar poly variety was superior in root length over the other varieties followed by Desprez poly $\mathrm{N}$ and then Pleno. Otherwise, Nejma and $\mathrm{H}$ poly varieties attained the lowest values of root length in both seasons. These results may be due to the genes expressions of varieties. These results are agreement with those obtained by Osman et al (2003), Aly (2006), Azzazy et al (2007) and Enan et al (2009).

Fayoum J. Agric. Res. \& Dev., Vol. 26, No.1, January, 2012 
Table 1: Variation in root growth, yields, quality\% and impurities \% traits at harvest in $2009 / 2010$ and $2010 / 2011$ seasons.

\begin{tabular}{|c|c|c|c|c|c|c|c|c|c|}
\hline Traits & \multicolumn{3}{|c|}{ Root growth traits } & Quality \% & \multicolumn{2}{|c|}{ Yields (t/fed) } & \multicolumn{3}{|c|}{ Impurities\% } \\
\hline \multicolumn{10}{|c|}{$2009 / 2010$} \\
\hline Varieties & $\begin{array}{c}\text { Root } \\
\text { length } \\
(\mathrm{cm})\end{array}$ & $\begin{array}{c}\text { Root } \\
\text { diameter } \\
(\mathbf{c m})\end{array}$ & $\begin{array}{c}\text { Root } \\
\text { fresh } \\
\text { weight } \\
\text { (g) }\end{array}$ & $\begin{array}{c}\text { Sucrose } \\
\%\end{array}$ & $\begin{array}{c}\text { Root } \\
\text { yield } \\
(t / \text { fed })\end{array}$ & $\begin{array}{c}\text { Sugar } \\
\text { yield } \\
(t / f e d)\end{array}$ & N\% & $\mathbf{N a} \%$ & $\mathbf{K} \%$ \\
\hline Oscar poly & 30.48 & 13.41 & 1278 & 15.47 & 32.05 & 4.96 & 1.97 & 1.75 & 5.85 \\
\hline Pleno & 27.79 & 13.33 & 1286 & 14.93 & 31.59 & 4.72 & 1.89 & 1.66 & 5.49 \\
\hline Desprez poly $\mathbf{N}$ & 28.65 & 13.91 & 1298 & 15.47 & 32.98 & 5.10 & 1.90 & 1.80 & 5.40 \\
\hline Nejma & 27.09 & 13.12 & 1287 & 15.80 & 32.18 & 5.08 & 1.75 & 1.58 & 5.00 \\
\hline H poly & 26.97 & 12.52 & 1271 & 15.53 & 32.32 & 5.02 & 2.05 & 1.90 & 5.65 \\
\hline LSD $5 \%$ & 0.61 & 0.31 & 21 & 0.21 & 0.91 & 0.06 & 0.02 & 0.04 & 0.19 \\
\hline \multicolumn{10}{|c|}{$2010 / 2011$} \\
\hline Oscar poly & 29.17 & 13.53 & 1300 & 15.72 & 32.84 & 5.16 & 2.02 & 1.86 & 5.75 \\
\hline Pleno & 26.64 & 13.19 & 1313 & 15.04 & 30.31 & 4.56 & 1.70 & 1.78 & 5.39 \\
\hline Desprez poly $\mathbf{N}$ & 27.08 & 13.92 & 1295 & 16.33 & 33.77 & 5.51 & 1.80 & 2.02 & 5.15 \\
\hline Nejma & 25.63 & 12.89 & 1145 & 16.58 & 31.25 & 5.18 & 1.51 & 1.70 & 4.90 \\
\hline H poly & 26.37 & 12.74 & 1319 & 15.76 & 32.29 & 5.09 & 1.95 & 2.07 & 5.50 \\
\hline LSD $5 \%$ & 0.81 & 0.52 & 26 & 0.11 & 0.73 & 0.04 & 0.02 & 0.02 & 0.09 \\
\hline
\end{tabular}

Root diameter of Desprez poly N variety out weighed the other varieties. This was true in both seasons with an exception compared with the other varieties in the in the $2^{\text {nd }}$ season where Oscar poly variety had root diameter similar to the increase that of Desprez poly N. This increase in root diameter may be attributed to the gene make up of varieties. Similar results were reported by Leilah et al (2005), Azzazy et al (2007), Enan et al (2009) and El-Sheikh et al (2009).

The differences between varieties in root fresh weight were insignificant except the case of Desprez poly $\mathrm{N}$ with $\mathrm{H}$ poly variety where there was significant difference for this trait. Sucrose percentage was variable between varieties in both seasons and the highest value was recorded for Nejma variety while the lowest value was obtained by Pleno. These results coincide with those finding recorded by Aly (2006), Azzazy et al. (2007) and El-Sheikh et al. (2009).

Varieties were significantly different in root and sugar yields/fed in the $1^{\text {st }}$ and $2^{\text {nd }}$ seasons. Desprez poly $\mathrm{N}$ variety surpassed the other varieties in root and sugar yields, where it attained 32.98 and $5.10 \mathrm{t} / \mathrm{fed}$. in the $1^{\text {st }}$ season, respectively. The corresponding values were 33.77 and $5.51 \mathrm{t} / \mathrm{fed}$. in the $2^{\text {nd }}$ season, respectively. Otherwise, Pleno variety attained the lowest for root and sugar yields/fed in both seasons. These differences may be due to the varietal genetic make up. These results are in line with those obtained by Aly (2006), Azzazy et al (2007), and Enan et al (2009).

Impurities content were significantly variable between varieties in both seasons. Nejma variety recorded the lowest impurities content compared with the other varieties. Similar results were found by Aly (2006) and Enan et al (2009). 
RESPONSE OF SOME SUGAR BEET GENOTYPES TO NITROGEN... 82

Table 2: Effect of nitrogen fertilizer levels on growth traits, yields, quality $\%$ and impurities\% at harvest in 2009/2010 and 2010/2011 seasons.

\begin{tabular}{|c|c|c|c|c|c|c|c|c|c|}
\hline Traits & \multicolumn{3}{|c|}{ Root growth traits } & Quality \% & \multicolumn{2}{|c|}{ Yields (t/fed) } & \multicolumn{3}{|c|}{ Impurities\% } \\
\hline \multicolumn{10}{|c|}{$2009 / 2010$} \\
\hline $\begin{array}{c}\text { Nitrogen } \\
\text { fertilizer } \\
\text { levels } \\
(\mathrm{kg} / \mathrm{fed})\end{array}$ & $\begin{array}{c}\text { Root } \\
\text { length } \\
(\mathbf{c m})\end{array}$ & $\begin{array}{c}\text { Root } \\
\text { diamet } \\
\text { er }(\mathrm{cm})\end{array}$ & $\begin{array}{c}\text { Root } \\
\text { fresh } \\
\text { weight } \\
\text { (g/plant) }\end{array}$ & $\begin{array}{c}\text { Sucrose } \\
\%\end{array}$ & $\begin{array}{c}\text { Root } \\
\text { yield } \\
(t / \text { fed })\end{array}$ & $\begin{array}{c}\text { Sugar } \\
\text { yield } \\
(t / f e d)\end{array}$ & $\mathbf{N \%}$ & $\mathrm{Na} \%$ & $\mathbf{K} \%$ \\
\hline 100 & 28.50 & 0 & 1170 & & & & 1.45 & 1.34 & 5.07 \\
\hline 120 & 29.60 & 14.40 & 11 & 15.29 & 32.38 & 4. & 1.70 & 1.54 & 5.35 \\
\hline 140 & 30.30 & 15.00 & 1453 & 14.93 & 34.06 & 5.09 & 1.98 & 1.73 & 5.45 \\
\hline LSD $5 \%$ & 0.40 & 0.31 & 11 & 0.29 & 0.81 & 0.02 & $\mathbf{0 . 0 3}$ & 0.06 & 0.07 \\
\hline \multicolumn{10}{|c|}{$2010 / 2011$} \\
\hline 100 & 29.40 & 14.75 & 1289 & 16.56 & 30.56 & 5.06 & 1.35 & 1.40 & 4.55 \\
\hline 120 & 30.70 & 15.15 & 1367 & 15.85 & 32.09 & 5.09 & 1.75 & 1.72 & 5.18 \\
\hline 140 & 32.20 & 16.20 & 1399 & 15.25 & 33.63 & 5.13 & 1.90 & 1.80 & 5.30 \\
\hline LSD 5\% & 0.12 & 0.18 & 13 & 0.17 & 0.62 & 0.02 & 0.03 & 0.08 & 0.05 \\
\hline
\end{tabular}

\section{Nitrogen levels effect:}

Data presented in Table (2) indicate that nitrogen levels significantly affected all the studied characteristics in both seasons. It was noticed that increasing $\mathrm{N}$ levels up to $140 \mathrm{~kg} \mathrm{~N} / \mathrm{fed}$ caused increases in all the studied traits except sucrose \% which was reduced by increasing $\mathrm{N}$ levels. The increases are amounted by $1.8-\mathrm{cm}, 2-\mathrm{cm}$ and $283 \mathrm{~g} / \mathrm{plant}$ in the $1^{\text {st }}$ season for root length, root diameter and root fresh weight corresponding to $2.8-\mathrm{cm}, 1.45-\mathrm{cm}$ and 110 $\mathrm{g} /$ plant in the $2^{\text {nd }}$ season, respectively. These results may be attributed to $\mathrm{N}$ role in excessive vegetative growth; increase in root length, diameter and then root fresh weight. These findings coincide with those obtained by Leilah $\boldsymbol{e t}$ al. (2005), Pytlarzkozicka (2005) and Abd El-Aal et al. (2010).

Otherwise, the reduction in sucrose was noticed when $\mathrm{N}$ level was increased up to $140 \mathrm{~kg} / \mathrm{fed}$, it may be due to the fact that increasing applied $\mathrm{N}$ resulted increasing water retention by the tap root and intern decrease sucrose $\%$ of root fresh weight (Draycott, 1972). This result is agreement with those reported by Leilah et al. (2005), Pytlarzkozicka (2005) and Abd El-Aal et al. (2010).

Yields of roots and sugar per feddan were increased by increasing $\mathrm{N}$ levels up to $140 \mathrm{~kg} / \mathrm{fed}$ in both seasons. The increases were 2.15 and $1.68 \mathrm{t}$ for roots and 0.08 and $0.14 \mathrm{t}$ for sugar when $\mathrm{N}$ level increased from 100 to $120 \mathrm{~kg}$ and from 120 to $140 \mathrm{~kg} \mathrm{~N} / \mathrm{fed}$ in the $1^{\text {st }}$ season, respectively. Corresponding to 1.53 and $1.54 \mathrm{t}$ for roots and 0.03 and $0.04 \mathrm{t}$ for sugar/fed in the $2^{\text {nd }}$ season, respectively. These increments in yields of roots could be due to the excessive vegetative growth i.e length, diameter and root fresh weight by increasing $\mathrm{N}$ level up to $140 \mathrm{~kg} \mathrm{~N} / \mathrm{fed}$. Also, the increments of sugar yield could be attributed to increase sucrose $\%$ and root yield. These results are coinciding with those obtained by Leilah et al. (2005), Pytlarzkozicka (2005) and Abd El-Aal et al. (2010).

Impurities content was increased by increasing $\mathrm{N}$ levels up to $140 \mathrm{~kg}$ $\mathrm{N} / \mathrm{fed}$. These increases in impurities were decreased quality $\%$ as sucrose $\%$ and decreased sugar yield as final product. This result is in line with those obtained

Fayoum J. Agric. Res. \& Dev., Vol. 26, No.1, January, 2012 
by Oldfield et al. (1979), Vendergeten and Venstallen (1991) and Leilah et al. (2005).

\section{C- Significant interactions:}

Results obtained in Table (3) show that sucrose\%, root yield and sugar yield were significantly affected by the interaction between varieties and $\mathrm{N}$ levels in both seasons. For sucrose\%, was noticed that adding $100 \mathrm{~kg} \mathrm{~N} / \mathrm{fed}$ gave the highest value of sucrose \% especially for the Nejma variety (16.93 and $17.10 \%$ ) in the $1^{\text {st }}$ and $2^{\text {nd }}$ seasons, respectively. Otherwise, increasing $\mathrm{N}$ level up to $140 \mathrm{~kg} \mathrm{~N} /$ fed decreased sucrose\% in all varieties especially for Pleno variety $(14.19$ and $14.50 \%)$ in the $1^{\text {st }}$ and $2^{\text {nd }}$ seasons, respectively. These results could be attributed to the gene make up of varieties and the role of $\mathrm{N}$ element which increase impurities content in roots and then decrease quality\%.

Table 3: Interaction between varieties and nitrogen fertilizer levels on quality and yields at harvest in 2009/2010 and 2010/2011 seasons.

\begin{tabular}{|c|c|c|c|c|c|c|c|c|c|}
\hline Traits & \multicolumn{3}{|c|}{ Sucrose\% } & \multicolumn{3}{|c|}{ Root yield (t/fed) } & \multicolumn{3}{|c|}{ Sugar yield (t/fed) } \\
\hline \multicolumn{10}{|c|}{$2009 / 2010$} \\
\hline \multicolumn{10}{|c|}{ Fertilizer levels (kg/fed) } \\
\hline Varieties & $100 \mathrm{~kg}$ & $120 \mathrm{~kg}$ & $\begin{array}{c}140 \\
\mathrm{~kg}\end{array}$ & $100 \mathrm{~kg}$ & $\begin{array}{c}120 \\
\mathrm{~kg}\end{array}$ & $140 \mathrm{~kg}$ & $100 \mathrm{~kg}$ & $120 \mathrm{~kg}$ & $140 \mathrm{~kg}$ \\
\hline Oscar poly & 15.47 & 15.70 & 15.24 & 30.60 & 32.51 & 33.05 & 4.73 & 5.10 & 5.04 \\
\hline Pleno & 15.91 & 14.68 & 14.19 & 30.00 & 31.92 & 32.85 & 4.77 & 4.69 & 4.66 \\
\hline Desprez poly N & 16.02 & 15.44 & 14.95 & 30.68 & 32.32 & 35.95 & 4.91 & 4.99 & 5.37 \\
\hline Nejma & 16.93 & 15.36 & 15.11 & 30.20 & 31.85 & 34.50 & 5.11 & 4.89 & 5.21 \\
\hline H poly & 16.16 & 15.26 & 15.16 & 29.68 & 33.32 & 33.95 & 4.80 & 5.08 & 5.15 \\
\hline LSD 5\% & & 0.10 & & & 0.17 & & & 0.04 & \\
\hline \multicolumn{10}{|c|}{$2010 / 2011$} \\
\hline Oscar poly & 16.53 & 15.51 & 15.12 & 31.90 & 32.40 & 34.23 & 5.27 & 5.03 & 5.18 \\
\hline Pleno & 15.87 & 14.75 & 14.50 & 28.37 & 31.26 & 31.30 & 4.50 & 4.61 & 4.54 \\
\hline Desprez poly N & 17.10 & 16.52 & 15.37 & 32.35 & 33.55 & 35.40 & 5.53 & 5.54 & 5.44 \\
\hline Nejma & 17.19 & 16.67 & 15.88 & 28.94 & 31.55 & 33.25 & 4.97 & 5.26 & 5.28 \\
\hline H poly & 16.13 & 15.78 & 15.36 & 31.22 & 31.67 & 33.98 & 5.04 & 5.00 & 5.22 \\
\hline LSD 5\% & & 0.20 & & & 0.19 & & & 0.05 & \\
\hline
\end{tabular}

For root yield, it was cleared that adding $140 \mathrm{~kg} \mathrm{~N} /$ fed for Desprez poly $\mathrm{N}$ variety attained the highest value of roots yield compared to the other interactions in the $1^{\text {st }}$ and $2^{\text {nd }}$ seasons, respectively. On the other hand, adding $100 \mathrm{~kg} \mathrm{~N} /$ fed to $\mathrm{H}$ poly variety recorded the lowest root yield in the $1^{\text {st }}$ season only and Pleno variety only in the $2^{\text {nd }}$ season, respectively. The increase in root yield may be due to excessive vegetative growth criteria length, diameter and fresh weight of individual root which all may be due to different responecs of the tested varieties those controlled by their genetic make up.

For sugar yield, it was noticed that increasing $\mathrm{N}$ level up to $140 \mathrm{~kg}$ $\mathrm{N} /$ fed with Desprez poly N variety gave the highest yield of sugar by $5.37 \mathrm{t} / \mathrm{fed}$, meanwhile adding $120 \mathrm{~kg} \mathrm{~N} / \mathrm{fed}$ with Desprez poly $\mathrm{N}$ variety gave the highest value of sugar yield by $5.54 \mathrm{t} / \mathrm{fed}$ in the $1^{\text {st }}$ and $2^{\text {nd }}$ seasons, respectively.

Fayoum J. Agric. Res. \& Dev., Vol. 26, No.1, January, 2012 


\section{REFERENCES}

Abd El-Aal, A.M.; A.I. Nafie and Ranya M. Abdel Aziz (2010). Response of some sugar beet genotypes to nitrogen fertilization under newly reclaimed land conditions. Egypt. J. Appl. Sci. 25 (6B): 194-208.

Abou Zeid, M.Y. and M.S.H. Osman (2005). Yield and quality of sugar beet as affected by bio and mineral fertilization. Egypt. J. Appl. Sci. 20 (8B): 416-433.

Aly, E.F.A. (2006). Effect of environmental conditions on productivity and quality of some sugar beet varieties. Ph. D. Thesis, Fac. of Agric. Benha Univ. Egypt.

Aly, M.H.A.; Zeinab R.M. and A.M.H. Osman (2009). Effect of seed inoculation and foliar application with Azospirillum brasiliense and/or Bacillus megatherium on productivity and quality of sugar beet. Egypt. J. Appl. Sci. 24 (2A): 56-70.

Azzazy, N.B., N.M.S. Shalaby and A.M. Abd El Razek (2007). Effect of planting density and days to harvest on yield and quality of some sugar beet varieties under Fayoum condition. Egypt J. Appl. Sci. 22 (12A):101-114.

Carruthers, A.; J.F.T. Oldfield and H.G. Teague (1962). Assessment of beet quality. $15^{\text {th }}$ Ann. Technical Conf., British Sugasr Corporation Ltd., 28 pp.

Draycott, A.P. (1972). Sugar beet Nutrition applied Science publishers LTd, Ripple Road, Barking, Essex, England, 250PP. (C.F. The Sugar Beet Crop Book, 572-573, $1^{\text {st }}$ Edition published by Chapman and Hall, Univ. Press, Cambridge, UK.).

El-Hinnawy, H.H.; E.A. Mahmoud; B.S.H. Ramadan; A.A. Farag and E.M. Al- Jebawi (2002). Phenotypic stability for some sugar beet genotypes. Recent technol. Agric. $2^{\text {nd }}$ Conf. Fac. Agric. Cairo. Univ. 2830 Oct.

El-Sheikh, S.R.E.; K.A.M. Khaled and S.A.A.M. Enan (2009). Evaluation of some sugar beet varieties under three harvesting dates. J. Agric. Sci. Mansoura Univ. 34 (3): 1559-1567.

Enan, S.A.A.M.; S.R.E. EI Sheikh and K.A.M. Khaled (2009). Evaluation of some sugar beet varieties under different levels of $\mathrm{N}$ and $\mathrm{Mo}$ fertilization. J. Biol. Chem. Environ. Sci. 4 (1): 345-362.

Leilah, A.A.; M.A. Badawi; E.M. Said; M.H. Ghonema and M.A.E. Abdou (2005). Effect of planting dates, plant population and $\mathrm{N}$ fertilization on sugar beet productivity under the newly reclaimed sandy soils in Egypt. Scientific J. of King Faical Univ. Basic and Applied Science, 6 (1): 95$110,1426$.

Le Docte, A. (1927). Commercial determination of sugar in the beet root using the sacks. Le-Docte Process. Int. Sug. J. 29: 488-492.

Neamet Alla, H.E.A. (2004). Effect of some agronomic practices on yield and quality of sugar beet. M.Sc. Thesis Fac. Agric. Tanta Univ.

Oldfield, J.F.T.; M. Shore; J.V. Dutton and H.G. Teague (1979). Assessment and reduction of sugar losses in beet sugar processing. In comptes. Rendus de La XVI. Assemblee Generale de la Commission International Technique de Sucrerie pp: 431-454.

Fayoum J. Agric. Res. \& Dev., Vol. 26, No.1, January, 2012 
Osman, A.M.H.; G.S. El-Sayed; M.S.H. Osman and K.S. El-Sogheir (2003). Soil application of some microelements with relation to yield and quality of sugar beet varieties. Annals of Agric. Sc. Moshtohor 41 (3): 1071-1088.

Osman, A.M.H.; El-Zeny Maha M. and A.I. Nafei (2010). An attempt to minimize mineral nitrogen fertilizer by use of nitrogen biofertilizer and their effects on sugar beet yield and quality in sandy reclaimed soils. Egypt. J. Appl. Sci. 25 (6 B): 209-218.

Page, A.L. (1982). "Methods of Soil Analysis" Chemical and microbiological properties ( $2^{\text {nd }}$ Ed.). Agron. 9 Am, Soc. Agron. Inc. Publ.. Midison, Wis, USA.

Pytlarzkozicka, M. (2005). The effect of nitrogen fertilization and anti-fungal plant protection on sugar beet yielding. Plant Soil Environ. 51 (5): 232236.

Shafika, N.M. and A.A. El Masry (2006). Effect of N and K fertilization with or without spraying by Fe combined with $\mathrm{Mn}$ on some physic chemical properties, productivity quality of sugar beet crop. Ann. Agric. Sc. Moshtohor 44 (4): 1431-1446.

Snedecor, G.W. and W.G. Cochran (1981). Statistical Methods $6^{\text {th }}$ Ed. Iowa State Univ. Press. Ames. Iowa. USA.

Vandrgeten, I. and M. Venstallen (1991). Wirkung einer reihenweisen Plazierung von optimalen $\mathrm{N}$ Mengen auf Ertrag und auf industrielle qualitat der Zuckerrube. $54^{\text {th }}$ Winter Cong. of the Inter. Inst. Sugar Beet Res.: 297-319.

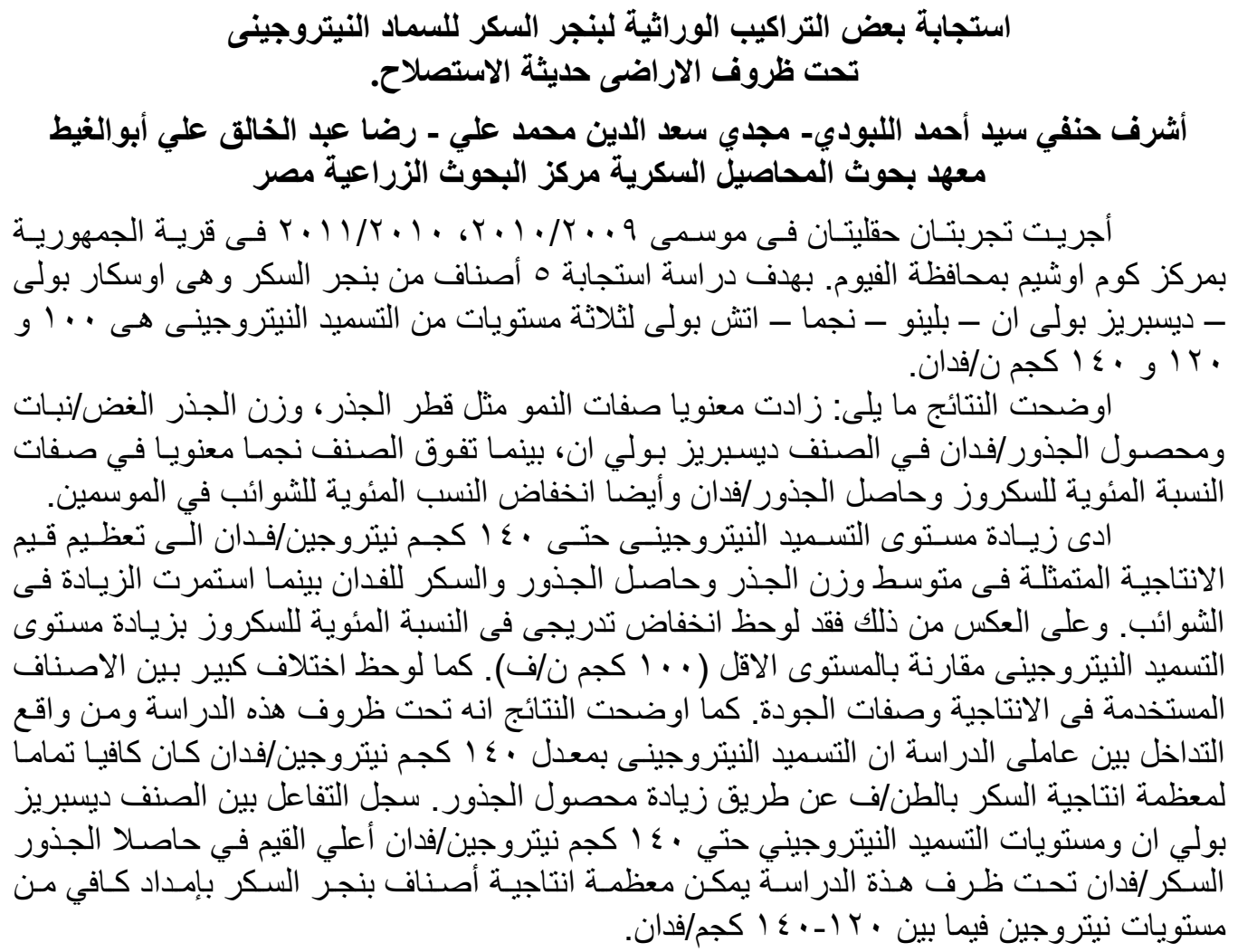

Fayoum J. Agric. Res. \& Dev., Vol. 26, No.1, January, 2012 